\title{
Pre-slaughtering factors related to bruises on cattle carcasses in the micro-region of Araguaína, Tocantins, Brazil
}

\section{Fatores pré-abate relacionados a lesões em carcaças bovinas na microrregião de Araguaína, Tocantins, Brazil}

\author{
Eduardo Feitosa Brito ${ }^{1 *}$; Luciano Fernandes Sousa ${ }^{2}$; Adriano Tony Ramos ${ }^{3}$; Daiane \\ Michele Frantz Sousa ${ }^{4}$; Bruno Marcell Paiva Costa ${ }^{5}$; Jorge Luís Ferreira ${ }^{2}$
}

\begin{abstract}
The objective of the study was to evaluate the main pre-slaughter factors contributing to bruising on cattle carcasses in the micro-region of Araguaína, Tocantins. The experiment was conducted from January to June using data from 414 cattle heads of different breeds, body weight and sex. Factors related to bruises in cattle were evaluated from the farms to a federally inspected slaughterhouse in Araguaína. The independent variables were road type, journey distance (paved and mixed roads), journey time (paved and mixed roads), driver's experience, prevalence of horns, sex class, falls during unloading, use of devices during unloading, truck maintenance conditions, presence of loose and/or protruding boards in the truck, condition of the truck floor, use of electric cattle prods during handling, presence of protruding nails and/or screws in the truck, arrangement of boards in the crowding pen, presence of broken boards in the cattle handling facility, angle of loading ramp, presence of protruding nails and/or screws in the cattle handling facility, and design and material of the cattle handling facility. The frequency of bruises was associated with the independent variables using contingency tables by the chi-square test $\left(\chi^{2}\right)$ to measure the association between variables. The variables road type, journey distance (mixed roads), journey time (mixed roads), animal behavior, falls during unloading, truck maintenance conditions, presence of loose and/or protruding boards in the truck, condition of the truck floor, arrangement of boards in the crowding pen, and presence of broken boards in the cattle handling facility had a significant effect on carcass bruising. Therefore, several pre-slaughter factors contribute to bruising on cattle carcasses.
\end{abstract}

Key words: Bruising. Injury. Management. Slaughterhouse.

\section{Resumo}

Objetivou-se avaliar os fatores principais na ocorrência de lesões traumáticas em carcaças bovinas associadas ao manejo pré-abate na microrregião de Araguaína, Tocantins. O experimento foi conduzido com 414 bovinos de diferentes raças, peso e sexo, de Janeiro a Junho de 2013. Foram avaliados fatores relacionados às lesões em carcaças bovinas, desde as propriedades rurais até o desembarque

' Discente do Curso de Doutorado do Programa de Pós-Graduação em Ciência Animal Tropical, Universidade Federal do Tocantins, UFTO, Campus de Araguaína, TO, Brasil. E-mail: britoef@uft.edu.br

2 Profs., UFTO, Campus de Araguaína, TO, Brasil. E-mail: luciano.sousa@mail.uft.edu.br; jlferreira@mail.uft.edu.br

3 Prof., Universidade Federal de Santa Catarina, UFC, Campus Curitibanos, SC, Brasil. E-mail: adriano.ramos@ufsc.br

4 Discente do Curso de Mestrado do Programa de Pós-Graduação em Sanidade Animal e Saúde Pública nos Trópicos, UFTO, Campus de Araguaína, TO, Brasil. E-mail: daianefrantz@msn.com

5 Médico Veterinário, Agência de Defesa Agropecuária do Estado do Tocantins, ADAPEC, Bandeirantes, TO, Brasil. E-mail: brunocosta_medvet@hotmail.com

* Author for correspondence 
no frigorífico sob Serviço de Inspeção Federal - SIF em Araguaína. As variáveis independentes foram: tipo de estrada, distância de transporte (somente estradas pavimentadas e estradas mistas), tempo de transporte (somente estradas pavimentadas e estradas mistas), atenção do condutor, presença de cornos nos animais, sexo dos animais, quedas dos animais no caminhão, uso de instrumentos ao desembarque, conservação do caminhão, tábuas soltas e/ou pontiagudas no caminhão, conservação do piso ou assoalho do caminhão, uso do bastão de choque elétrico no caminhão, prego e/ou parafuso com ponta exposta no caminhão, disposição das tábuas na seringa, tábuas quebradas no curral, declividade na rampa de embarque, prego e/ou parafuso com ponta exposta no curral, formato do curral e material para cercar o curral. A frequência de ocorrência das lesões traumáticas foi associada às variáveis independentes por meio de tabelas de contingência usando o índice de qui-quadrado $\left(\mathrm{X}^{2}\right)$ para medir o efeito da associação. As variáveis: tipo de estrada, distância de transporte (estradas mistas), tempo de transporte (estrada mista), comportamento dos animais, quedas dos animais no caminhão de transporte, conservação do caminhão de transporte, tábuas soltas e/ou pontiagudas no caminhão, conservação do piso ou assoalho do caminhão, disposição das tábuas da seringa e tábuas quebradas no curral apresentaram efeito na ocorrência de lesões traumáticas. Conclui-se baseado nos resultados obtidos que devido ao manejo préabate em suas várias vertentes, que promove a ocorrência de lesões traumáticas em carcaças bovinas.

Palavras-chave: Contusão. Frigorífico. Hematoma. Manejo.

\section{Introduction}

The Brazilian cattle herd is considered the largest commercial herd in the world, with over 212 million heads (IBGE, 2016). In 2015, more than 30 million cattle heads were slaughtered, representing production of approximately 7.5 million tons of meat (IBGE, 2015). Around 15 million cattle heads were slaughtered in the first half of 2016 (IBGE, 2016), making Brazil one of the largest beef producers and exporters in the world. In 2014, the cattle herd in the North region corresponded to 45,826,142 heads, and the state of Tocantins had the third largest herd of this region with more than 8 million cattle heads, representing $18 \%$ of the total herd in North Brazil (IBGE, 2016). Cattle farming is one of the pillars of the Tocantins economy, with a total of 529,244 cattle heads slaughtered in officially inspected slaughterhouses in the first half of 2016 (IBGE, 2016). The municipality of Araguaína has the third largest cattle herd in the state of Tocantins with approximately 228,312 heads (ADAPEC, 2017), and its economy is strongly dependent on beef cattle production.

In quantitative terms, Brazil's international prominence in beef production is evident. However, meat quality is influenced by several aspects, including bruises due to inadequate facilities, careless handling and incorrect transportation, which are evidenced after slaughtering (ASSIS et al., 2011). In Brazil, livestock is mainly transported on roads by two-axle trucks (JOAQUIM, 2002). Trucks without adequate conditions of use are considered a risk factor for the occurrence of carcass injuries. According to Romero and Sánchez (2012), improper transport can lead to carcass bruising, in addition to a significant increase in stress and eventually death of livestock.

During their lifetime, cattle require well-trained personnel with good management skills to reduce the occurrence of bruising and economic losses both at the farm and during transportation (EMBRAPA, 2015). However, the low levels of education in the rural labor force and personnel responsible for transporting animals, besides the lack of training opportunities (MAIA; RODRIGUES, 2012), are associated with the reduced application of good management practices, thus increasing the occurrence of bruises in cattle.

Carcass bruising is an indicator of poor handling during the transportation process from grazing paddocks to the slaughterhouse facilities and restraining box. Bruises can be classified according to their total area, the timing of occurrence and depth of the injured site (POLIZEL NETO et al., 2015). 
Therefore, the last 24 hours before slaughter plays a prominent role in carcass bruising because most of the lesions are caused by inappropriate management during this period (ANDRADE et al., 2008).

Considering the importance of the beef cattle market to the economy of Brazil and Tocantins and the need to improve meat quality to meeting the increasingly demanding consumer market in terms of better animal welfare, it is essential to understand the influence of pre-slaughter factors on the occurrence of bruising in cattle carcasses. The objective of the study was to evaluate the main pre-slaughter factors contributing to bruising on cattle carcasses in the micro-region of Araguaína, Tocantins.

\section{Material and Methods}

The study was conducted using data randomly collected from 414 cattle heads of different breeds, body weight and sex. Data relative to pre-slaughter factors were collected through interviews and on-site observations on farms during loading, transportation, unloading and slaughter, which were listed in descriptive worksheets per farm. The road type, driver's experience, characteristics of the animals, handling during unloading, truck maintenance conditions and characteristics of the cattle handling facilities on the farms were described.

The farms that authorized data collection and provided animals for the study were: Farm A1 (Bandeirantes/TO) - 36 heads, Farm A2 (Bandeirantes/TO) - 17 heads, Farm B1 (Santa Fé/ TO) - 72 heads, Farm B2 (Santa Fé/TO) - 18 heads, Farm C (Wanderlândia/TO) - 38 heads, Farm D (Arapoema/TO) - 89 heads, Farm E (Araguaína/ TO) - 18 heads, Farm F1 (Piraquê/TO) - 108 heads, and Farm F2 (Piraquê/TO) - 108 heads.

The road type was classified according to the pavement used for transporting cattle from the farm to the slaughterhouse as paved roads (asphaltic pavement) or mixed roads, in which the journey occurred part on paved roads and part on dirt roads.

The journey distance was divided into categories of less than $50 \mathrm{~km}, 50$ to $100 \mathrm{~km}$ and more than $100 \mathrm{~km}$ for cattle transported on mixed roads. For animals transported on paved roads, journey distance was divided into categories of less than $50 \mathrm{~km}$ and more than $50 \mathrm{~km}$. The journey time was divided into categories of less than $60 \mathrm{~min}, 60$ to $120 \mathrm{~min}$ and more than 120 min for cattle transported on mixed roads, whereas it was divided into categories of less than $60 \mathrm{~min}$ and more than $60 \mathrm{~min}$ for animals transported on paved roads.

Driver's experience was evaluated by observing their concern for the animals transported, stopping the truck when necessary to observe the animals and identify any problems. The driver should also check if cattle are standing, helping them to stand up if they are lying down on the truck floor.

Animals' intrinsic characteristics were evaluated in loads per truck considering the prevalence of horns, and animal sex. Loads of cattle with horns and mixed loads (comprised of horned and hornless animals) and loads of male cattle and mixed loads (comprised of males and females) were considered. Although classified as mixed loads, males and females were transported in separate cages within the truck.

Variables related to handling during unloading at the slaughterhouse were: falls during unloading and use of devices during unloading.

Relative to the overall truck condition, the following variables were evaluated: presence of loose and/or protruding boards in the truck, protruding nails and/or screws in the truck, and condition of the truck floor (good, regular or poor). The use of electric cattle prods during handling, and truck maintenance conditions (acceptable or unacceptable) were also evaluated.

The evaluated characteristics of the cattle handling facilities on the farm included: presence 
of broken boards and protruding nails and/or screws that could harm the animals, and the angle of the loading ramp (greater or less than $20 \%$ ), which was obtained by dividing the ramp height by its length and then multiplying the result by 100 . In addition, the arrangement of boards in the crowding pen was evaluated and classified as solid (less than $15 \mathrm{~cm}$ between them) or spaced (more than $15 \mathrm{~cm}$ ). The construction material used for fencing the cattle handling facility was classified as wood or wire cord, while the design of the cattle handling facility was classified as square or curved.

The animals were slaughtered in a federally inspected slaughterhouse in the municipality of Araguaína, Tocantins.

Bruise incidence was observed during routine inspections of the slaughter line by examining the medial and lateral sides of the caudal and cranial portions of the half carcasses. Bruises were also evaluated by a veterinarian during the final carcass inspection.

The number, location and color of bruises were recorded in a specific worksheet for each animal. The timing of occurrence was visually evaluated, with bruises of bright red color indicative of recent lesion and yellow-brown bruises indicative of old lesions, according to Strappini et al. (2010).

Bruises were the only type of lesion considered, not including scratches, fractures, dislocations and sprains. Bruise incidence numbers were acquired by counting the number of bruises on the carcass at the slaughter line after animal skinning.

The frequency of bruises was associated with the independent variables using contingency tables by the chi-square test $\left(\chi^{2}\right)$ at a significance level of $5 \%$ to measure the association between variables.

\section{Results and Discussion}

Cattle transported on mixed roads corresponded to $86.5 \%$ of total cattle evaluated, and $65.9 \%$ of them presented some lesion. Injured animals transported on paved roads represented $4.59 \%$ of the total cattle evaluated.

There was an effect of road type $(\mathrm{P}<0.0001)$ on the frequency of bruises in cattle. Thus, animals transported on paved roads are less likely to have some degree of bruising (Table 1).

The journey distance for animals transported on paved roads was divided into categories of less than $50 \mathrm{~km}$ and more than $50 \mathrm{~km}$, with a total of 56 animals evaluated. The occurrence of bruising was affected by the journey distance $(\mathrm{P}=0.0004)$. Therefore, the greater the distance traveled, the higher the occurrence of bruising (Table 1).

Cattle transported on mixed roads corresponded to 358 heads, and $59.8 \%$ of them traveled more than $100 \mathrm{~km}$ while only $5 \%$ traveled less than 50 $\mathrm{km}$. There was a significant effect $(\mathrm{P}=0.0122)$ of journey distance on the frequency of bruises in cattle. Therefore, the occurrence of bruising was lower in cattle transported for distances below 50 $\mathrm{km}$ on mixed roads compared to animals traveling greater distances (Table 1).

In this study, the occurrence of bruising in cattle transported for distances below $50 \mathrm{~km}$ differed significantly from those that traveled more than 50 $\mathrm{km}$. On the other hand, Pellecchia (2014) observed a higher occurrence of bruising in cattle traveling greater distances (300-500 km) compared to lower distances (0-200 km) when evaluating 22,234 cattle heads in the state of São Paulo. This discrepancy can be related to differences in road conditions, intrinsic climatic factors and the temperament of experimental animals, which were mostly Zebu animals.

Journey distance and time may not be directly related to carcass bruising, since they are influenced by the type of road and its condition, the type of truck and even the experience and training of the driver (PELLECCHIA, 2014).

Only 56 cattle heads were transported on paved 
roads, and $33.9 \%$ of them presented some lesion. Animals transported for up to $60 \mathrm{~min}$ had fewer bruises than cattle transported for more than 60 min. Therefore, the journey time on paved roads influenced the occurrence of bruises in cattle (Table 1). These results do not correspond with those presented by Valdés (2002), who evaluated two different journey times ( 3 and 16 hours) in 120 cattle heads in Chile. The author reported a higher frequency of bruises in animals transported for shorter periods, which can be justified by their similar genotype, body weight, age and origin. However, cattle in the present study did not show any similarity regarding these factors.

Cattle transported on mixed roads corresponded to 358 heads. The journey time on mixed roads was divided into three categories, and injured animals accounted for $65.9 \%$ of all cattle studied. There was an effect $(\mathrm{P}=0.0122)$ of journey time on the occurrence of bruising (Table 1). Therefore, animals transported for periods below $60 \mathrm{~min}$ showed fewer bruises than animals from the other categories. In addition to the expected results, these results are also supported by the literature. Reimann et al. (2015) evaluated 4,438 carcasses in the state of Rio Grande do Sul and reported less carcass bruising in animals transported for 2-3 hours compared to those transported for periods of 3-5 hours. The wide variety of classes studied by Reimann et al. (2015) for the variable journey time (six categories) may partially explain some of the effects found in the present study (two classes).

Table 1. Variables related to the transport of cattle and occurrence of bruising in carcasses in a federally inspected slaughterhouse in the State of Tocantins.

\begin{tabular}{|c|c|c|c|c|c|}
\hline \multirow{2}{*}{ Variable } & \multirow{2}{*}{ Classes } & \multicolumn{2}{|c|}{ Occurrence of bruising } & \multirow{2}{*}{ Total } & \multirow{2}{*}{$\mathrm{P}^{*}\left(\chi^{2}\right)$} \\
\hline & & Yes & No & & \\
\hline \multirow{2}{*}{$\mathrm{RT}^{1}$} & Paved road & $19(33.9 \%)$ & $37(66.1 \%)$ & 56 & \multirow{2}{*}{$<0.0001$} \\
\hline & Mixed road & $236(65.9 \%)$ & $122(34.1 \%)$ & 358 & \\
\hline \multirow{2}{*}{$\mathrm{JDPR}^{2}$} & Less than $50 \mathrm{~km}$ & $7(18.4 \%)$ & $31(81.6 \%)$ & 38 & \multirow{2}{*}{0.0004} \\
\hline & More than $50 \mathrm{~km}$ & $12(66.7 \%)$ & $6(33.3 \%)$ & 18 & \\
\hline \multirow{3}{*}{$\mathrm{JDMR}^{3}$} & Less than $50 \mathrm{~km}$ & $7(38.9 \%)$ & $11(61.1 \%)$ & 18 & \multirow{3}{*}{0.0122} \\
\hline & 50 to $100 \mathrm{~km}$ & $78(61.9 \%)$ & $48(38.1 \%)$ & 126 & \\
\hline & More than $100 \mathrm{~km}$ & $151(70.6 \%)$ & $63(29.4 \%)$ & 214 & \\
\hline \multirow{2}{*}{$\mathrm{JTPR}^{4}$} & Less than $60 \mathrm{~min}$ & $7(18.4 \%)$ & $31(81.6 \%)$ & 38 & \multirow{2}{*}{0.0004} \\
\hline & More than $60 \mathrm{~min}$ & $12(66.7 \%)$ & $6(33.3 \%)$ & 18 & \\
\hline \multirow{3}{*}{$\mathrm{JTMR}^{5}$} & Less than $60 \mathrm{~min}$ & $7(38.9 \%)$ & $11(61.1 \%)$ & 18 & \multirow{3}{*}{0.0122} \\
\hline & 60 to $120 \mathrm{~min}$ & $78(61.9 \%)$ & $48(38.1 \%)$ & 126 & \\
\hline & More than $120 \mathrm{~min}$ & $151(70.6 \%)$ & $63(29.4 \%)$ & 214 & \\
\hline
\end{tabular}

${ }^{1}$ Road type; ${ }^{2}$ journey distance on paved roads; ${ }^{3}$ journey distance on mixed roads; ${ }^{4}$ journey time on paved roads; ${ }^{5}$ journey time on mixed roads.

*Probability of a type I error (chi-square test $\left.-\chi^{2}\right)$.

Driver's experience was evaluated by observing their concern for the animals transported. The driver was cautious if he observed the cattle during the journey and stopped the truck when animals were lying down or trampled. The drivers were accompanied by an evaluator during the transport.

Driver's experience did not affect the occurrence of bruising (Table 2). Therefore, paying attention to the transported cattle did not reduce the number of bruises $(\mathrm{P}=0.9152)$. Overall, drivers transported 
the animals at very low speed so there were few falls during transport. However, we cannot assure that drivers would transport animals at very slow speed if the journey had not been accompanied by our team.

The transport of horned animals corresponded to $17.4 \%$ of total cattle evaluated, and $11.6 \%$ of them presented some lesions. Bruises were observed in $60.5 \%$ of cattle transported in mixed loads, representing $81.2 \%$ of bruised cattle. In this study, there was no effect $(\mathrm{P}=0.3302)$ of transporting horned or mixed cattle on the occurrence of bruising (Table 2).

The literature reports that the presence of horns increases the incidence of bruising. For instance, Ghezzi et al. (2008) reported a higher incidence of bruising in $59.8 \%$ of loads with at least one horned animal when evaluating the transport of 15,361 cattle heads in the La Plata region. Additionally, Minka and Ayo (2007) also reported a higher incidence of bruising due to the presence of horns in a group of 150 animals.

In the present study, a total of eight loads of mixed cattle were evaluated. These animals were handled together within the same areas and paddocks in the farm of origin, which may explain why those results are not consistent with the literature. Moreover, there were no loads with hornless animals only, which makes it difficult to compare and elucidate this effect.

Bruises are influenced by the sex class (YEH et al., 1978). The probability of bruising is influenced by the physical characteristics of males and females, including already reported differences in skin thickness and subcutaneous fat thickness between sex classes in cattle (WEEKS et al., 2002).

In this study, a total of 216 animals were transported in loads of male cattle only while 198 animals were transported in trucks with males and females. There was no transport of females alone. Although classified as mixed loads, males and females were transported in separate cages within the truck. Approximately $61.1 \%$ of bruises occurred in animals transported in mixed loads, representing $47.45 \%$ of all bruised cattle. There was no effect ( $P$ $=0.8466)$ of sex on the occurrence of bruising in cattle (Table 2), probably because males and females were transported in separate cages within the truck, which is similar to loads of male cattle only.

The effect of sex on the occurrence of bruising in cattle is widely reported in the literature. Vara et al. (2014) evaluated 10,769 animals and reported a higher incidence of bruising in females (1.95) compared to males (1.04). Nicholson (2008) evaluated 2,824 cattle and reported that $65.8 \%$ of female carcasses were bruised compared to $50.8 \%$ of male carcasses. Claudio (2012) observed an incidence of bruising of $81.3 \%$ for females and $35 \%$ for males, while Roeber et al. (2001) reported values of $88.2 \%$ and $52.9 \%$, respectively. Vara et al. (2014) reported a higher incidence of bruising in females (141.75\% - more than one lesion per carcass) compared to males (79.33\%). In a study with 5,257 animals, Hoffman and Lühl (2012) observed higher bruise levels in heifers compared to steers, higher severe bruising in cows than in heifers, and reported that $83 \%$ of carcasses condemned for bruising were from old cows.

There are some reasons for the higher occurrence of bruising in females. According to Strappini et al. (2010), females are more susceptible to bruising because of their lower fat cover in the carcass, leaving the muscles more exposed as fatty tissue offers some protection against external impacts. Moreover, the higher female slaughter age and, consequently, body weight and size are a likely cause of the higher occurrence of bruising on female carcasses (REBAGLIATI et al., 2005). Ghezzi et al. (2008) mentioned the highest prevalence of horned animals among adult cows as a reason for the greater occurrence of bruising in females.

Another justification for the higher occurrence of bruising in females during transport is the different temperament of Bos taurus males and females (TITTO et al., 2010). Temperament is 
defined as a set of individuals' behaviors, generally attributed to fear (FORDYCE et al., 1982). Anxiety and fear in cattle are not desired, as they result in stress and decreased well-being. Temperament is a trait of economic importance because reactive cattle have lower carcass yield and meat quality due to contusions and stress (COSTA, 2000).

Although most authors report a higher occurrence of bruising in females, Romero et al. (2013) reported more bruises in males $(41.2 \%)$ than females $(26.5 \%)$ when evaluating data from 1,179 animals. However, the same authors stated that females are highly reactive during the pre-slaughter period, resulting in higher $\mathrm{pH}$ values compared to males. On the other hand, Civeira et al. (2006) did not observe a significant difference between males and females when evaluating the frequency of bruising, corroborating the results of the present study.

Unloading at the slaughter facility is one of the most critical moments in the meat production chain. During this period, all the handling procedures must be performed correctly to avoid the occurrence of bruising on cattle carcasses.

Falls during unloading were reported in $30.2 \%$ of the cattle, and $72.8 \%$ of them presented some lesions. A total of $64.3 \%$ cattle transported in loads with the occurrence of falls were bruised, and even in loads with no occurrence of falls approximately $39.6 \%$ of the carcasses had some injury. Falling during unloading affected $(\mathrm{P}=0.0020)$ the occurrence of bruising in cattle (Table 2). It suggests that special care should be taken during this important stage of animal transport.

It is expected that cattle will leave the truck naturally when arriving at the slaughterhouse. However, yelling, hand clapping and flags are frequently used for resistant animals (COSTA et al., 2010). In severe cases or when cattle are lying down, the use of electric cattle prods is recommended according to their own rules of use (SILVA, 2012).

Loads that used devices during unloading represented $91.3 \%$ of the cattle, and $60.9 \%$ of them presented some lesions. Contrary to the expected outcome, the use of devices during unloading did not increase the occurrence of bruising. This result is related to the fact that devices were not used during unloading in only one load of cattle, which accounts for only $8.7 \%$ of all cattle studied (Table 2).

The truck is an essential factor in pre-slaughter management. Therefore, the aim is to minimize its influence on the occurrence of bruising in cattle carcasses. The variables evaluated in this study were the presence of loose and/or protruding boards in the truck, the presence of protruding nails and/or screws in the truck, the use of electric cattle prods during handling, truck maintenance conditions and the condition of the truck floor.

Table 2. Variables related to the truck driver, animal characteristics, unloading management and occurrence of bruising in carcasses in a federally inspected slaughterhouse in the State of Tocantins.

\begin{tabular}{|c|c|c|c|c|c|}
\hline \multirow{2}{*}{ Variable } & \multirow{2}{*}{ Classes } & \multicolumn{2}{|c|}{ Occurrence of bruising } & \multirow{2}{*}{ Total } & \multirow{2}{*}{$\mathrm{P}^{*}\left(\chi^{2}\right)$} \\
\hline & & Yes & No & & \\
\hline \multirow{2}{*}{$\mathrm{DE}^{1}$} & Absent & $55(61.1 \%)$ & $35(38.9 \%)$ & 90 & \multirow{2}{*}{0.9152} \\
\hline & Present & $200(61.7 \%)$ & $124(38.3 \%)$ & 324 & \\
\hline \multirow{2}{*}{$\mathrm{PH}^{2}$} & Horned & $48(66.7 \%)$ & $24(33.3 \%)$ & 72 & \multirow{2}{*}{0.3302} \\
\hline & Mixed & $207(60.5 \%)$ & $135(39.5 \%)$ & 342 & \\
\hline \multirow{2}{*}{ Sex } & Male & $134(62 \%)$ & $82(37 \%)$ & 216 & \multirow{2}{*}{0.8466} \\
\hline & Mixed & $121(61.1 \%)$ & $77(38.9 \%)$ & 198 & \\
\hline
\end{tabular}


continuation

\begin{tabular}{llcccc}
\hline \multirow{2}{*}{ FDU $^{3}$} & Absent & $164(56.8 \%)$ & $125(43.2 \%)$ & 289 & \multirow{2}{*}{0.0020} \\
\cline { 2 - 5 } & Present & $91(72.8 \%)$ & $34(27.2 \%)$ & 125 & \\
\hline \multirow{2}{*}{ UDDU $^{4}$} & Absent & $25(69.4 \%)$ & $11(30.6 \%)$ & 36 & \multirow{2}{*}{0.3108} \\
\cline { 2 - 5 } & Present & $230(60.9 \%)$ & $148(39.1 \%)$ & 378 & \\
\hline \multirow{2}{*}{ TOTAL } & & $\mathbf{2 5 5}$ & $\mathbf{1 5 9}$ & $\mathbf{4 1 4}$ & \\
\hline
\end{tabular}

${ }^{1}$ Driver's experience; ${ }^{2}$ prevalence of horns; ${ }^{3}$ falls during unloading; ${ }^{4}$ use of devices during unloading.

*Probability of a type I error (chi-square test $-\chi^{2}$ ).

Trucks with loose and/or protruding boards transported $43 \%$ of the total cattle studied, which corresponded to $49.4 \%$ of all bruising events. In loads of animals transported with this inadequacy, $70.8 \%$ of cattle presented a lesion. There was an effect $(\mathrm{P}=0.0008)$ of the presence of loose and/ or protruding boards on the occurrence of bruising in cattle (Table 3). On the other hand, the presence of protruding nails and/or screws in the truck did not affect $(\mathrm{P}=0.8724)$ the occurrence of bruising in cattle compared to that in trucks with proper conditions (Table 3). These risk factors should be investigated because it is known that animals during transport are at greater risk of colliding with these structures, resulting in injuries and bruises. Thus, fewer loads of animals transported in trucks with protruding nails and screws avoided their contact with these structures, reducing the occurrence of bruising.

The use of electric cattle prods during handling was not associated $(\mathrm{P}=0.0529)$ with carcass bruises, as there was no significant effect in loads in which the electric cattle prods were not used (Table 3). This result is possibly related to drivers' awareness about using electric cattle prods.

The type of truck floor and its conservation can be associated with the incidence of bruising in cattle carcasses, as they can trigger slipping, falling and/ or trampling (TSEIMAZIDES, 2006). The most commonly used floor types include cattle grids and thick rubber; however, rubber flooring reduces vibration, has greater stability and provides comfort to animals (COSTA et al., 2010).

All trucks in this study had grid floors, although they had different conservation conditions (classified as poor, regular and good). Most cattle (57\%) were transported in trucks with floors in good condition, and these animals accounted for $50.6 \%$ of all bruised animals. The condition of the truck floor affected (P $=0.0012$ ) the occurrence of bruising in cattle (Table $3)$. It is irrefutable that adequate flooring reduces bruises in cattle, primarily by avoiding slipping, falling and trampling.

Overall truck condition was classified as acceptable (new) or unacceptable (old trucks). Approximately $69.6 \%$ of cattle transported in old trucks presented injuries while $49.4 \%$ of cattle transported in new trucks were bruised. Only $31.8 \%$ of the total cattle injured were transported in new trucks. The occurrence of bruising in cattle was affected $(\mathrm{P}<0.0001)$ by the conservation of the truck (Table 3). It is known that trucks in adequate conditions do not have many objects that could harm the animals, providing them with more comfort. 
Table 3. Truck-related variables and occurrence of bruising in carcasses in a federally inspected slaughterhouse in the State of Tocantins.

\begin{tabular}{|c|c|c|c|c|c|}
\hline \multirow{2}{*}{ Variable } & \multirow{2}{*}{ Classes } & \multicolumn{2}{|c|}{ Occurrence of bruising } & \multirow{2}{*}{ Total } & \multirow{2}{*}{$\mathrm{P}^{*}\left(\chi^{2}\right)$} \\
\hline & & Yes & No & & \\
\hline \multirow{2}{*}{$\mathrm{TMC}^{1}$} & Acceptable & $81(49.4 \%)$ & $83(50.6 \%)$ & 164 & \multirow{2}{*}{$<0.0001$} \\
\hline & Unacceptable & $174(69.6 \%)$ & $76(30.4 \%)$ & 250 & \\
\hline \multirow{2}{*}{$\mathrm{LPBT}^{2}$} & Absent & $129(54.7 \%)$ & $107(45.3 \%)$ & 236 & \multirow{2}{*}{0.0008} \\
\hline & Present & $126(70.8 \%)$ & $52(29.2 \%)$ & 178 & \\
\hline \multirow{3}{*}{$\mathrm{CTF}^{3}$} & Poor & $33(62.3 \%)$ & $20(37.7 \%)$ & 53 & \multirow{3}{*}{0.0012} \\
\hline & Regular & $93(74.4 \%)$ & $32(25.6 \%)$ & 125 & \\
\hline & Good & $129(54.6 \%)$ & $107(45.4 \%)$ & 236 & \\
\hline \multirow{2}{*}{$\mathrm{UECPH}^{4}$} & Absent & $142(66 \%)$ & $73(34 \%)$ & 215 & \multirow{2}{*}{0.0529} \\
\hline & Present & $113(56.8 \%)$ & $86(43.2 \%)$ & 199 & \\
\hline \multirow{2}{*}{$\mathrm{PNST}^{5}$} & Absent & $233(61.5 \%)$ & $146(38.5 \%)$ & 379 & \multirow{2}{*}{0.8724} \\
\hline & Present & $22(62.9 \%)$ & $13(37.1 \%)$ & 35 & \\
\hline TOTAL & & 255 & 159 & 414 & \\
\hline
\end{tabular}

${ }^{1}$ Truck maintenance conditions; ${ }^{2}$ loose and/or protruding boards in the truck; ${ }^{3}$ condition of the truck floor; ${ }^{4}$ use of electric cattle prods during handling; ${ }^{5}$ protruding nails and/or screws in the truck.

*Probability of a type I error (chi-square test $\left.-\chi^{2}\right)$.

The characteristics of the cattle handling facilities on the farm included the angle of the loading ramp, arrangement of boards in the crowding pen, the presence of broken boards, protruding nails and/ or screws, and the design and material of the cattle handling facility.

There was an effect $(\mathrm{P}=0.0002)$ of the arrangement of boards in the crowding pen and the presence of broken boards in the cattle handling facility on the occurrence of bruising in cattle (Table 4). It is inferred that the incidence of bruises is lower in crowding pens with solid sides. Similarly, the presence of broken boards in the cattle handling facility resulted in a greater number of lesions in cattle. It is well known that the direct contact of animals with those structural inadequacies might injure them.
The independent variables: construction material used for fencing $(\mathrm{P}=0.1717)$, design of the cattle handling facility $(\mathrm{P}=0.9152)$, angle of the loading ramp $(\mathrm{P}=0.3108)$ and presence of protruding nails and/or screws $(P=0.4339)$ did not affect the occurrence of bruising (Table 4). Therefore, aspects such as the geometric design of the cattle handling facility (square or curved) and the angle of the loading ramp (greater or less than $20 \%$ ) did not increase bruises in cattle. In the same way, the presence of nails and/or screws did not influence the occurrence of bruising ( $\mathrm{P}=0.4339$ ), probably because pens were not crowded, leaving more space available for animals. 
Table 4. Variables related to the cattle handling facility on the farm, and occurrence of bruising in carcasses in a federally inspected slaughterhouse in the State of Tocantins.

\begin{tabular}{|c|c|c|c|c|c|}
\hline \multirow{2}{*}{ Variable } & \multirow{2}{*}{ Classes } & \multicolumn{2}{|c|}{ Occurrence of bruising } & \multirow{2}{*}{ Total } & \multirow{2}{*}{$\mathrm{P} *\left(\chi^{2}\right)$} \\
\hline & & Yes & No & & \\
\hline \multirow{2}{*}{$\mathrm{ABCP}^{1}$} & Solid & $62(48.4 \%)$ & $66(51.6 \%)$ & 128 & \multirow{2}{*}{0.0002} \\
\hline & Spaced & $193(67.5 \%)$ & $93(32.5 \%)$ & 286 & \\
\hline \multirow{2}{*}{$\mathrm{BBCHF}^{2}$} & Absent & $117(53.7 \%)$ & $101(46.3 \%)$ & 218 & \multirow{2}{*}{0.0005} \\
\hline & Present & $138(70.4 \%)$ & $58(29.6 \%)$ & 196 & \\
\hline \multirow{2}{*}{$\mathrm{ALR}^{3}$} & Less than $20 \%$ & $25(69.4 \%)$ & $11(30.6 \%)$ & 36 & \multirow[t]{2}{*}{0.3108} \\
\hline & More than $20 \%$ & $230(60.9 \%)$ & $148(39.1 \%)$ & 378 & \\
\hline \multirow{2}{*}{$\mathrm{PNSCHF}^{4}$} & Absent & $197(60.6 \%)$ & $128(39.4 \%)$ & 325 & \multirow{2}{*}{0.4339} \\
\hline & Present & $58(65.2 \%)$ & $31(34.8 \%)$ & 89 & \\
\hline \multirow{2}{*}{$\mathrm{DCHF}^{5}$} & Square & $200(61.7 \%)$ & $124(38.3 \%)$ & 324 & \multirow{2}{*}{0.9152} \\
\hline & Curved & $55(61.1 \%)$ & $35(38.9 \%)$ & 90 & \\
\hline TOTAL & & 255 & 159 & 414 & \\
\hline \multirow{2}{*}{$\mathrm{MCHF}^{6}$} & Wood & $137(63.7 \%)$ & $78(36.3 \%)$ & 215 & \multirow{2}{*}{0.1717} \\
\hline & Wire rope & $82(56.6 \%)$ & $63(43.4 \%)$ & 145 & \\
\hline TOTAL & & 219 & 141 & 360 & \\
\hline
\end{tabular}

${ }^{1}$ Arrangement of boards in the crowding pen; ${ }^{2}$ broken boards in the cattle handling facility; ${ }^{3}$ angle of loading ramp; ${ }^{4}$ protruding nails and/or screws in the cattle handling facility; ${ }^{5}$ design of the cattle handling facility; ${ }^{6}$ material of the cattle handling facility.

*Probability of a type I error (chi-square test $\left.-\chi^{2}\right)$.

\section{Conclusion}

Road type and condition as well as journey distance and time had a significant effect on the occurrence of bruising in cattle carcasses.

The prevalence of horns and sex class did not contribute to bruising on cattle carcasses.

Truck-related variables such as the condition of the floor, presence of loose and/or protruding boards and overall truck condition influenced the occurrence of bruising in cattle carcasses.

\section{Acknowledgments}

To CNPq for financial support.

To UFT for supporting the development and implementation of this study.

\section{References}

AGÊNCIA DE DEFESA AGROPECUÁRIA DO ESTADO DO TOCANTINS - ADAPEC. (2017). Rebanhos por município no Estado do Tocantins: referência Maio de 2017. Disponível em: http://intranet. adapec.to.gov.br/intranet/. Acesso em: 10 out. 2017.

ANDRADE, E. N.; ROÇA, R. O.; SILVA, R. A. M. S.; GONÇALVES, H. C.; PINHEIRO, R. S. B. Prevalência de lesões em carcaças de bovinos de corte abatidos no Pantanal Sul Mato-Grossense transportados por vias fluviais. Ciência e Tecnologia de Alimentos, v. 28, n. 4, p. 822-829, 2008.

ASSIS, D. R.; REZENDE-LAGO, N. C. M.; MARCHI, P. G. F.; D'AMATO, C. C. Perdas diretas ocasionadas por abscessos e hematomas em carcaças de bovinos. Revista Portuguesa de Ciências Veterinárias, v. 106, n. 577-580, p. 47-51, 2011.

CIVEIRA, M. P.; RENNER, R. M.; VARGAS, R. E. S.; RODRIGUES, C. N. (2006). Avaliação do bem-estar animal em bovinos abatidos para consumo em frigorífico do Rio Grande do Sul. Veterinária em Foco, Canoas, v. 4, n. 1, p. 5-11, 2006. 
CLAUDIO, L. D. G. Fatores associados a injuria muscular em bovinos abatidos e suas relações com enzimas séricas e qualidade da carcaça. Dissertação (Mestrado em Medicina Preventiva) - Faculdade de Ciências Agrárias e Veterinárias, Universidade Estadual Paulista, Jaboticabal.

COSTA, M. J. R. P. Ambiência na produção de bovinos de corte a pasto. In: ENCONTRO ANUAL DE ETOLOGIA, 18., 2000, Florianópolis. Anais... Florianópolis: Sociedade Brasileira de Etologia, 2000. p. 26-42.

COSTA, P. M. J. R.; QUITILIANO, M. H.; TSEIMAZIDES, S. P. Boas práticas de manejo: transporte. Jaboticabal, SP: Funep, 2010. 56 p.

EMPRESA BRASILEIRA DE PESQUISA AGROPECUÁRIA - EMBRAPA. Manual de boas práticas de vacinação e imunização de bovinos. Bagé: EMBRAPA Pecuária Sul, 2015. (Circular técnica, 47).

FORDYCE, G.; GODDARD, M.; SEIFERT, G. W. The measurement of temperament in cattle and effect of experience and genotype. Animal Production in Australia, Queesland, v. 14, p. 329-332, 1982.

GHEZZI, M. D.; ACERBI, R.; BALLERIO, M.; REBAGLIATI, J. E.; DIAZ, M. D.; BERGONZELLI, P.; CIVIT, D.; RODRÍGUEZ, E. M.; PASSUCCI, J. A.; CEPEDA, R.; SAÑUDO, M. E.; COPELLO, M.; SCORZIELO, J.; CALÓ, M.; CAMUSSI, E.; BERTOLI, J.; ABA, M. A. Evaluacion de las practicas relacionadas con el transporte terrestre de hacienda que causan perjuicios economicos en la cadena de ganados y carnes. Córdoba, Argentina: Instituto de Promoción de la Carne Vacuna, 2008. (Cuadernillo técnico, 5).

HOFFMAN, L. C.; LÜHL, J. Causes of cattle bruising during handling and transport in Namibia. Meat Science, v. 92, n. 2, p. 115-124, 2012. doi: 10.1016/j. meatsci.2012.04.021.

INSTITUTO BRASILEIRO DE GEOGRAFIA E ESTATÍSTICA - IBGE. Sistema IBGE de recuperação automática. Banco de tabelas estatísticas. 2016. Disponível em: http://www.sidra.ibge.gov.br=1. Acesso em: 15 maio 2019.

INSTITUTO BRASILEIRO DE GEOGRAFIA E ESTATÍSTICA - IBGE. Animais abatidos e peso total das carcaças, segundo os meses - Brasil. $4^{\circ}$ trimestre de 2015. 2015. Disponível em: http:// www1.ibge.gov.br/ home/estatistica/indicadores/ agropecuaria/producaoagropecuaria/abate-leite-couroovos_201504_1.shtm. Acesso em: 15 maio 2019.

JOAQUIM, C. F. Efeitos da distância de transporte em parâmetros post-mortem de carcaças bovinas.
2002. Dissertação (Mestrado) - Faculdade de Medicina Veterinária e Zootecnia, Universidade Estadual Paulista, Botucatu.

MAIA, L. R.; RODRIGUES, L. B. Saúde e segurança no ambiente rural: uma análise das condições de trabalho em um setor de ordenha. Ciência Rural, Santa Maria, v. 42, n. 6, p. 1134-1139, 2012.

MINKA, N. S.; AYO, J. O. Effects of loading behaviour and road transport stress on traumatic injuries in cattle transported by road during the hot-dry season. Livestock Science, v. 107, n. 1, p. 91-95, 2007. doi: 10.1016/j. livsci.2006.10.013

NICHOLSON, J. D. W. National market cow and bull beef quality audit-2007: a survey of producer-related defects. 2008. Masters (Dissertation, Office of Graduate Studies) - Texas A\&M University, College Station, Texas.

PELleCCHIA, A. J. R. Caracterização do risco de hematomas em carcaças bovinas. 2014. Dissertação (Mestrado) - Faculdade de Ciências Agrárias e Veterinárias, Universidade Estadual Paulista, Jaboticabal.

POLIZEL NETO, A.; ZANCO, N.; LOLATTO, D. C. J.; MOREIRA, P. S. A.; DROMBOSKI, T. Perdas econômicas ocasionadas por lesões em carcaças de bovinos abatidos em matadouro-frigorífico do norte de Mato Grosso. Pesquisa Veterinária Brasileira, v. 35 , n. 4 , p. $324-328,2015$. doi: 10.1590/S0100736X2015000400002

REBAGLIATI, J. E.; BALLERIO, M.; ACERBI, R.; DIAS, M.; ALVAREZ, M. de lós M.; BIGATTI, F.; CRUZ, J. A.; SCITELLI, L.; ERGONZELLI, P.; GONZALEZ, C.; CIVIT, D. Evaluación de las prácticas ganaderas en bovinos que causan perjuicios económicos en plantas frigoríficas de la República Argentina. Revista Electrónica de Veterinaria, Malaga, v. 9, n. 10b, p. 1-40, 2005.

REIMANN, F. A.; MENDONÇA, F. S.; VARA, C. C.; TAMARA, J. Q.; CARDOSO, F. F.; VAZ, R. Z. Fatores de rico para ocorrência de lesões em carcaças bovinas. Tempo e distância de transporte. In: ENCONTRO DE PÓS-GRADUAÇÃO UFPEL, 17., 2015, Pelotas. Anais... Pelotas: UFPEL, 2015.

ROEBER, D. L.; MIES, P.D.; SMITH, C. D.; BELK, K. E.; FIELD, T. G.; TATUM, J. D.; SCANGA, J. A.; SMITH, G. C. National market cow and bull beef quality audit-1999: a survey of producer-related defects in market cows and bulls. Journal of Animal Science, v. 79, n. 3, p. $658-665$, 2001. doi: $10.2527 / 2001.793658 x$

ROMERO, M. H.; URIBE-VELÁSQUEZ, L. F.; SÁNCHEZ, J. A.; MIRANDA-DE LA LAMA, G. C. Risk factors influencing bruising and high muscle $\mathrm{pH}$ 
in Colombian cattle carcasses due to transport and preslaughter operations. Meat Science, v. 95, n. 2, p. 256263, 2013. doi: 10.1016/j.meatsci.2013.05.014

ROMERO, M. P.; SANCHEZ, J. V. Bienestar animal durante el transporte y surelación con la calidad de la carne bovina. Revista MVZ Córdoba, v. 17, n. 1, p. 29362944, 2012.

SILVA, C. V. B. O. Abate humanitário e o bem-estar animal em bovinos. Trabalho (Conclusão de Curso) Faculdade de Veterinária, Universidade Federal do Rio Grande do Sul, Porto Alegre.

STRAPPINI, A. C.; FRANKENA, K.; METZ, J. H. M.; GALLO, B; KEMP, B. Prevalence and risk factors for bruises in Chilean bovine carcasses. Meat Science, v. 86, n. 3, p. 859-864, 2010.doi: 10.1016/j.meatsci.2010.07.010

TITTO, E. A. L.; TITTO, C. G.; GATTO, E. G.; NORONHA, C. M. S.; MOURÃO, G. B.; NOGUEIRA FILHO, J. C. M.; PEREIRA, A. M. F. Reactivity of Nellore steers in two feedlot housing systems and its relationship with plasmatic cortisol. Livestock Science, Amsterdãn, v.129, n. 1-3, p. 146-150, 2010.doi: 10.1016/j. livsci.2010.01.017

TSEIMAZIDES, S. P. Efeitos do transporte rodoviário sobre a incidência de hematomas e variações de pH em carcaças bovinas. 2006. Dissertação (Mestrado) - Faculdade de Ciências Agrárias e Veterinárias, Universidade Estadual Paulista, Jaboticabal.
VALDÉS, A. M. Efectos de dos densidades de carga y dos tiempos de transporte sobre el peso vivo, rendimiento de la canal y presencia de contusiones en novillos destinados al faenamiento. 2002. Trabalho (Conclusão de Curso) Facultad de Ciencias Veterinarias, Universidad Austral de Chile, Valdivia.

VARA, C. C.; M., F. S.; GONÇALVES, G. V. B.; MANZONI, V. G.; VAZ, F. N.; VAZ, R. Z. Efeito do sexo dos animais sobre a ocorrência de contusões em carcaças bovinas. In: CONGRESSO DE INICIAÇÃO CIENTIFICA DA UNIVERSIDADE FEDERAL DE PELOTAS, 23., 2014, Pelotas, RS. Anais... Pelotas, 2014. Disponível em: http://wp.ufpel.edu. br/gecapec/files/2014/09/EFEITO-DO-SEXO-DOSANIMAIS-SOBRE-A-OCORR $\%$ C3\%8ANCIA-DECONTUS \%C3\%95ES-EM-CARCA\%C3\%87ASBOVINAS.pdf. Acesso: 23 fev. 2017.

WEEKS, C.; MCNALLY, P.; WARRIS, P. Influences of the design of facilities at auction markets and animal handling procedures on bruising in cattle. The Veterinary Record, London, v. 150, n. 24, p. 743-748. 2002. doi: $10.1136 /$ vr. 150.24 .743

YEH, E.; ANDERSON, B.; JONES, P.; SHAW, F. (1978). Bruising in cattle transported over long distances. The Veterinary Record, London, v. 103, n. 6, p. 117-119, 1978. doi: 10.1136/vr.103.6.117 